\title{
Problems and perspectives of archaeological heritage management in intensively used agricultural landscapes - best-practice models from Saxony (Germany)
}

Michael STROBEL

\begin{abstract}
Nowhere else is there a creeping and slow destruction of archaeological monuments as in intensively used agricultural landscapes. Sites are still degraded by erosion, cultivation and pollutant inputs to the soil. But the implementation of concrete measures needs more than sensitive archaeological institutions. Without the cooperation with farmers, agricultural administrations, nature conservation agencies and organisations as well as the mobilisation of agro-environmental funds archaeologists will never achieve an efficient heritage management on intensively cultivated areas. In order to protect the rural archaeological heritage in Saxony, various strategies have been developed since 2000. The paper presents best-practice models of managing monuments in intensively used agricultural landscapes. The conversion of ploughed sites into grassland alongside with the application of precision farming systems are especially effective approaches to a better conservation of archaeological remains at risk.
\end{abstract}

Key-words: Agriculture, erosion, management of archaeological landscapes, middle saxon loess hill region, archaeological monuments at risk, precision farming, ploughing.

Alongside the "Leipzig Tieflandsbucht" and the "Dresden Basin" the Middle Saxon Loess Hill region is considered the most important ancient settlement landscape in Saxony characterized by more than 7.000 years of agricultural tradition that began with the early Linear Pottery Culture. ${ }^{1}$ The settlements of these earliest farmers were established on the best loamy Loess soils (fig. 1). At all times and prehistoric periods, the environmental potentials were favouring a permanent use of land and a continuous occupation. The density of monuments is

${ }^{1}$ H. Stäuble, Linien- und stichbandkeramische Kulturen. In: R. Heynowski, R. Reiss (Red.), Urund Frühgeschichte Sachsens. Atlas zur Geschichte und Landesjunde von Sachsen. Beiheft zur Karte B I 1.1.-1.5 (Leipzig und Dresden 2010) 24-42. M. Strobel, T. Westphalen, Landwirtschaft und archäologische Denkmalpflege im mittelsächsischen Lößhügelland. In: Sachsen. Zukunft aus Herkunft. Festschrift 100 Jahre Landesverein Sächsischer Heimatschutz 1908-2008 (Dresden 2008) 151-155. M. Strobel, Th. Westphalen, 7500 Jahre bäuerliche Besiedlung in der Lommatzscher Pflege - von den Anfängen im 5. Jahrtausend v. Chr. bis ins 11. Jh. n. Chr. Sonderheft „Lommatzscher Pflege“ der Sächsischen Heimatblätter. In print. 


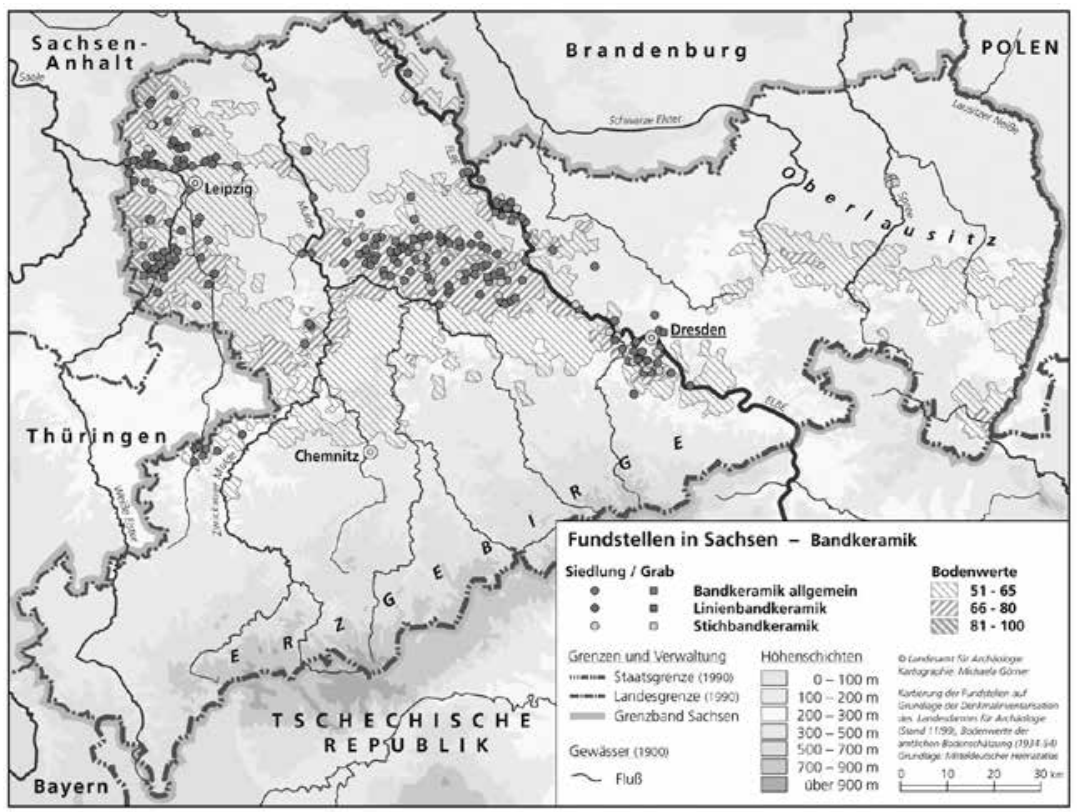

Fig. 1 In Saxony settlements of the Linear Pottery Culture were established on best loamy Loess soils. The today's most productive agricultural regions are the oldest archaeological landscapes.

much larger than in other regions of Saxony. Some 650 archaeological remains are listed in an area of about $300 \mathrm{~km}^{2} .2$

The biggest risks to this rich archaeological heritage arise from intensive agriculture; for centuries the intensification of farming has been a continuous process. The damage that results to archaeological features can be attributed to a variety of processes that had undoubtedly started in prehistoric times and reached probably the first climax in the late Bronze Age.

After farmers were dissolved form feudal patterns in the middle of the $19^{\text {th }}$ century they intensified and changed their use of land (Fig. 2). ${ }^{3}$ These processes included:

2 F. Ende et al., Archäologie und Landwirtschaft. Zwischenbilanz eines Modellprojektes in der Lommatzscher Pflege. In: Ausgrabungen in Sachsen 2, 2010, 121-130. H. Behm et al., Deutsches Bundesstiftung Umwelt (DBU) (Hrsg.), Archäologie und Landwirtschaft. Wege zu einem partnerschaftlichen Verhältnis in Hochertragslandschaften. Erfahrungen aus einem Modellprojekt in der Lommatzscher Pflege (Freistaat Sachsen) (Osnabrück 2011. Onlineversion: http://www.landesarchaeologen.de/fileadmin/Dokumente/Dokumente_Verband/ Publikationen/Archaeologie_und_Landwirtschaft.pdf). F. Ende et al.., Landwirtschaft und Archäologie in der Lommatzscher Pflege - Bilanz eines von der Deutschen Bundesstiftung Umwelt geförderten Modellprojektes. Archäologisches Nachrichtenblatt 17, 2012, 145-153.

3 M. Strobel, Archäologische Denkmalpflege in sächsischen Agrarlandschaften. Naturschutzarbeit in Sachsen 54, 2012, 4-15. 


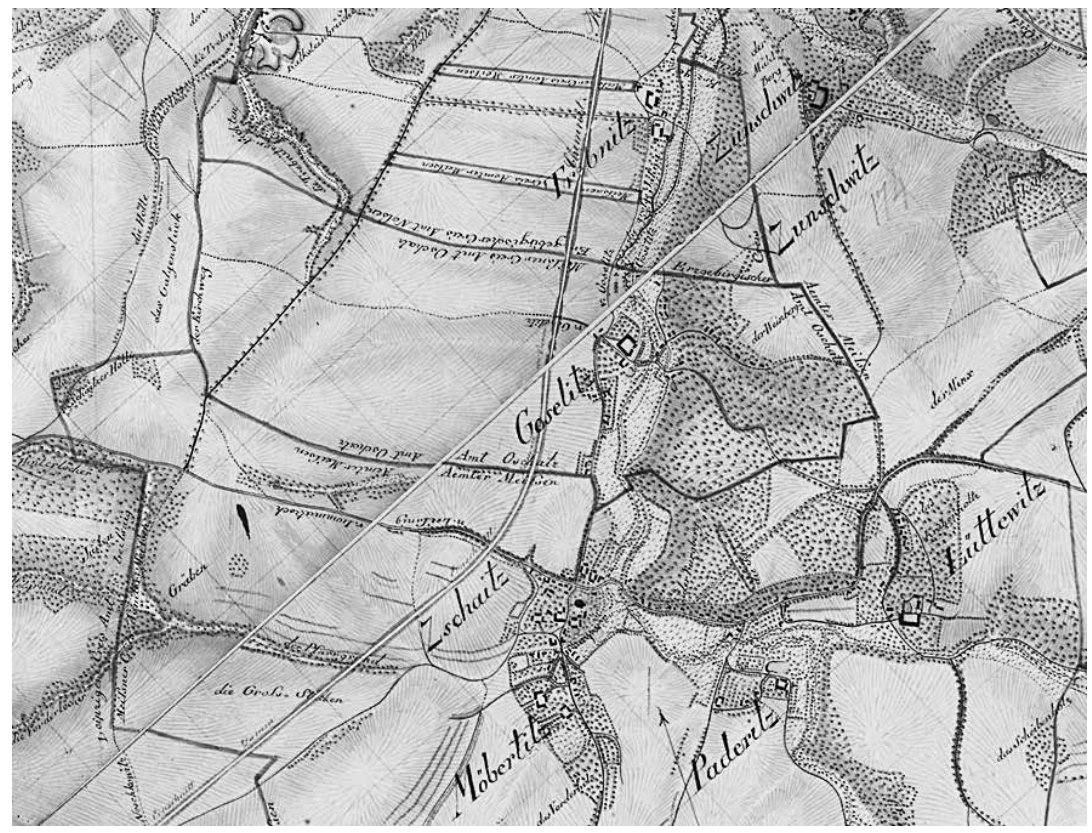

Fig. 2 Old maps inform about the changes of cultural landscapes since the 19th century.

- The deforestation for farming purposes:

Forests are often acting as important repositories of well-preserved archaeological remains like fortifications and grave hills. In the Middle Saxon Loess Hill region as well as in other Saxon landscapes woodland was reduced gradually during the $19^{\text {th }}$ century and converted to arable land. Previously uncultivated areas were cultivated know.

- The removal of historic boundary features such as terraces, hedges, and walls

- The draining of small rivers and ponds

- The use of bigger and more powerful farm machinery as well as the adoption of more invasive cultivation methods:

Farmers invested in more effective ploughs and other machines in order to prepare their fields for the cultivation of sugar beet crops. One of the most innovative and successful manufacturers of ploughs was the agricultural machine factory Rudolf Sack in Leipzig that produced and exported tens of thousands machines worldwide up to the twenties. The factory was expropriated in 1945, privatized in 1999 and integrated into the Amazon company in 1999. However, the purchase of a steam plough or a modern tractor was profitable only for big farming enterprises or land owners. Since 1890 the more invasive ploughing led 
to the discovery of an increasing number of archaeological sites. Some inquisitive farmers detected very important finds, became enthusiastic collectors of prehistoric antiquities and built up their own private museums. ${ }^{4}$ On the other hand, archaeologists very soon recognized that the agricultural intensification and the abandonment of traditional land management systems threaten not only buried archaeological remains or paleo-environmental features, but also the historic landscape. The detection and destruction of monuments are representing two sides of the same coin. ${ }^{5}$

In Saxony, during the 1970s, features were regularly damaged or gradually leveled and whole earthwork complexes were lost as a result of extensive land consolidation measures. In order to maximize the machinery use fields were expanded to 100 ha without taking in account natural boundaries, pathways of water or slopes vulnerable to erosion (Fig 3). The regular use of chisels and deep

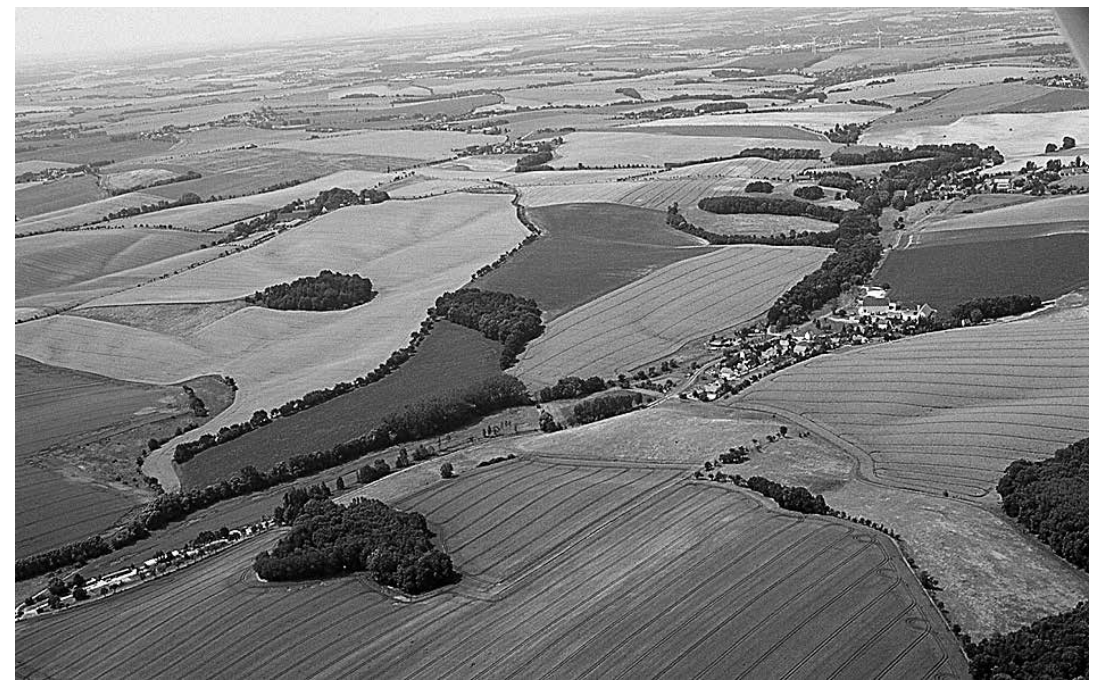

Fig. 3 The Middle Saxon Loess Hill Region is characterised by giant fields (Foto: R. Heynowski).

ploughing intensified soil degradation. At the beginning of the 1980s, the transition to an industrialized agriculture was completed at the expense of the environmental impact. Nowadays, these structures, created 40 years ago, are very attractive to modern, efficient farming companies.

4 M. Strobel, Alfred Hennig (1886-1916). Ein fast vergessener Pionier siedlungsarchäologischer Forschung in Sachsen. Archaeo 6, 2009, 41-47. M. Fröhner, M. Strobel, Zwei Landwirte als Archäologen: Max Andrä (1866-1946) und Oskar Wallrabe (1870-1956). Archaeo 13, 2017, 38-47.

5 M. Strobel, Archäologische Denkmalpflege in sächsischen Agrarlandschaften. Naturschutzarbeit in Sachsen 54, 2012, 4-15. 
Normally, the impacts on the archaeological resources arising from construction and development are routinely assessed, mitigated and managed on the basis of legal requirements attached to spatial planning and development-control licensing systems. Large-scale rescue excavations are always the second best solution, but determine the archaeologist's everyday work.

In contrast, agriculture, forestry, and related land use lie outside the controls imposed by these systems. Most routine farming practices such as arable cultivation do not need any planning permission. Their impacts are generally neither assessed, licensed or subject of any form of management. This absence of any structured archaeological response makes it probable that these processes rather than construction represent the greatest threat to the archaeological heritage and a significant challenge to the heritage management.

The Middle Saxon Loess Hill region is still vulnerable to erosion (Fig. 4). Periodically intense precipitation events cause severe on- and off-site damages (Fig. 5) and contribute to massive floods of the Elbe river. The archaeological sites situated here are more threatened by erosion than in other regions of Saxony.

Compaction of soils, increasing rates of erosion and deep ploughing can be assumed to be having seriously detrimental effects on archaeological deposits for which soils provide a protective matrix. The most urgent and widespread thre-

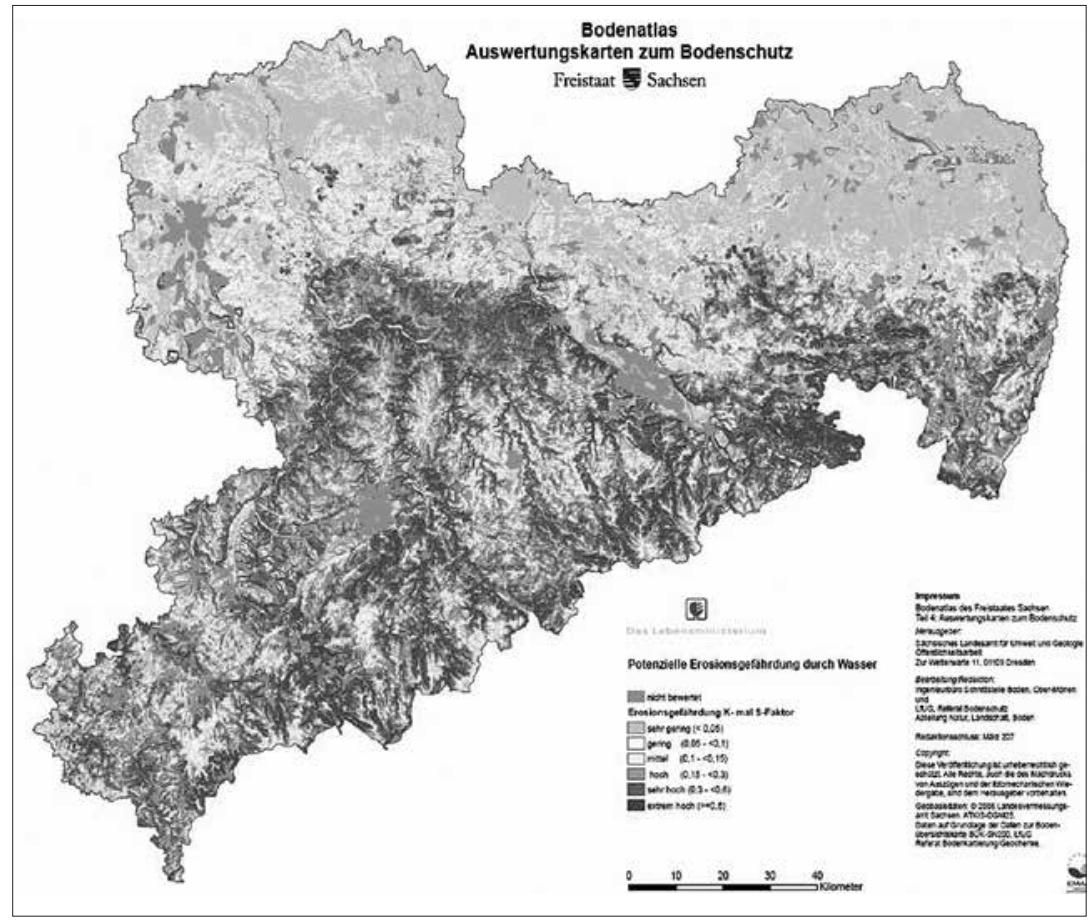

Fig. 4 Map of the soil erosion risk in Saxony. 


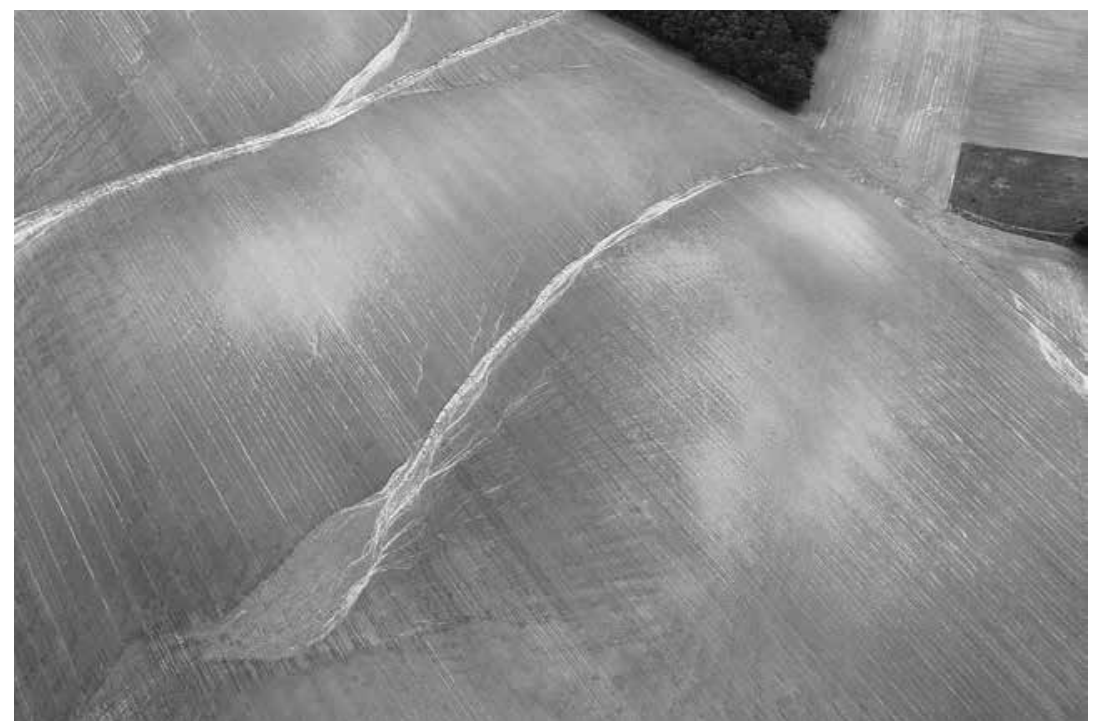

Fig. 5 On-site erosion damages concern also archaeological monuments (Foto: R. Heynowski).

ats to soil resources also concern archaeological remains. Especially, graves are suffering from the effects of deep ploughing (Fig. 6). The extent of the damages can't be quantified and varies according to the original depth of the burials. Even a cemetery believed to be completely destroyed can still provide well-preserved cremations. Nevertheless continuing long-term tillage might be most damaging to monuments and leveling walls or grave hills. At Hof-Stauchitz, for example,

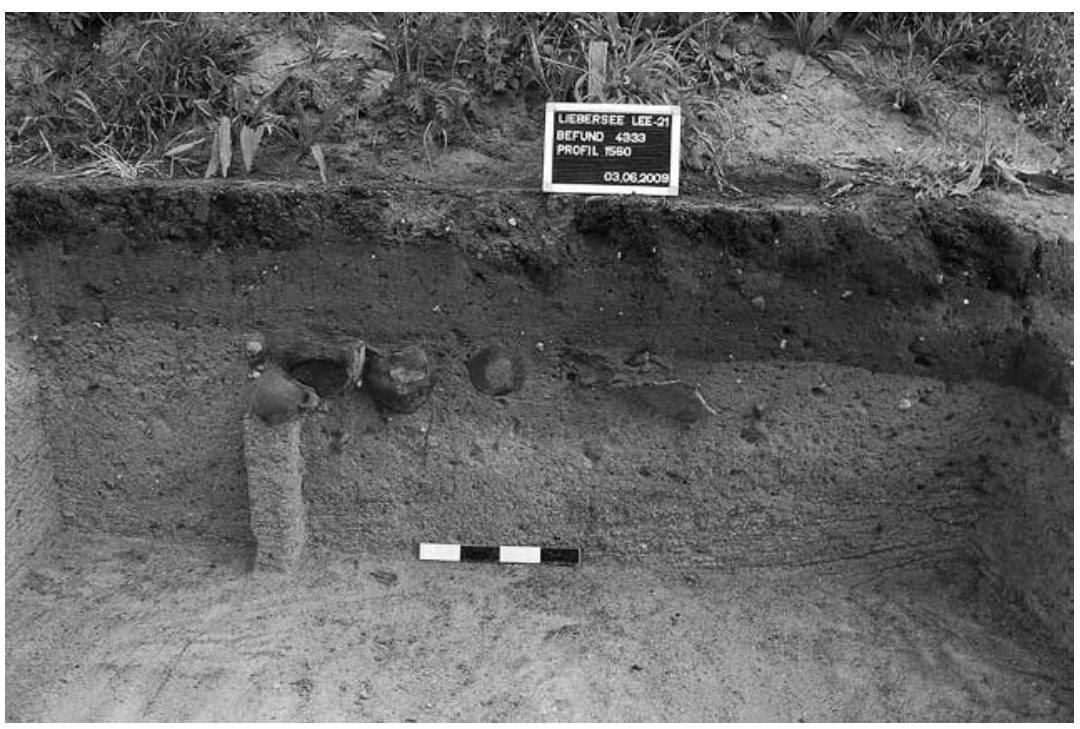

Fig. 6 Ploughing has an important damaging impact on graves. 


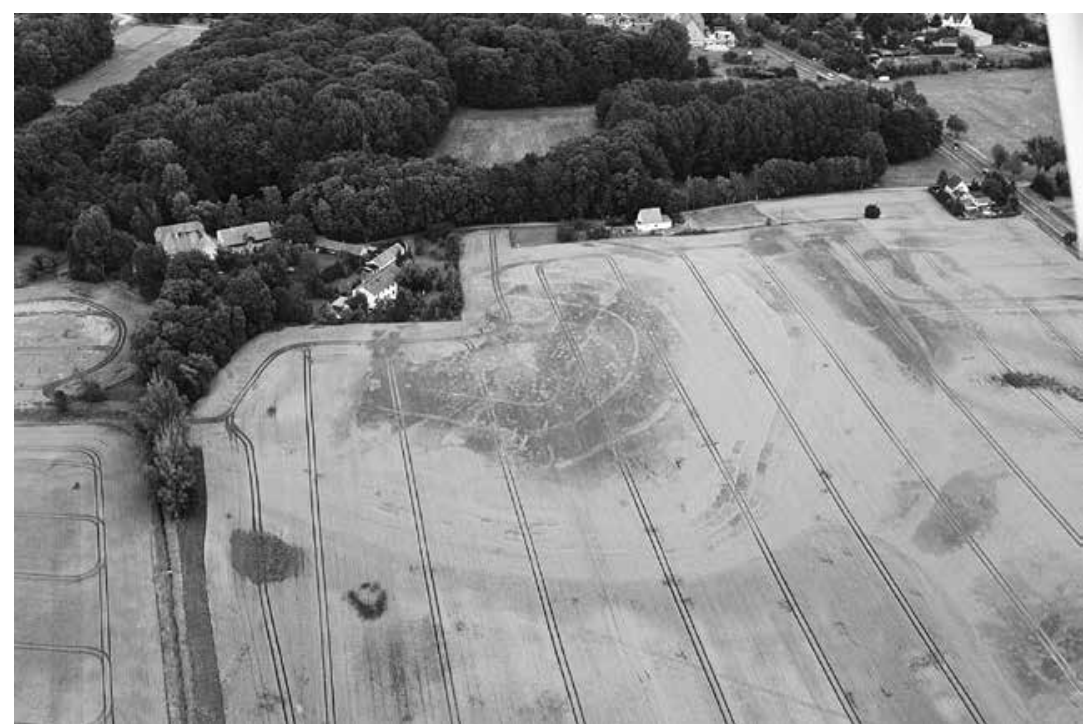

Fig. 7 Wooden construction of a medieval fortification (Hof-Stauchitz) is severely at risk nearing its complete leveling (Foto: R. Heynowski).

cultivation continues to damage an early medieval fortification that presented a well-preserved wall in 1910. Since that time the loss of height is more than $1 \mathrm{~m} .^{6}$ The wall reinforced with a box-shaped wooden construction is severely at risk nearing it's completely leveling (Fig. 7).

Effective action requires improved understanding of the archaeological remains, although their large number makes the selection of a representative sample essential. Assessing the state of preservation of sites is an especially important factor for informing future actions. The differences in the state of preservation, depending on relief an other local factors, are taken in account by compiling a detailed survey of a limited number of archaeological sites representing all prehistoric and medieval periods. Three dimensional models reveal the current risks and allow for the simulation of scenarios with changing parameters (rainfall, soil cover, sowing, etc.). In addition, test excavations and other pedological analyses give insights into the state of the monument over time. ${ }^{7}$

Protective measures need to be based on a detailed knowledge of the monument, preferably in its landscape context. Several factors need to be taken into

${ }^{6}$ M. Rummer, Chr. Schubert, M. Strobel und Th. Westphalen, Ist „Gana“ noch zu retten? Neue Untersuchungen zum Zustand der frühmittelalterlichen Burganlage von Hof/Stauchitz (Kreis Nordsachsen/Meißen). Mitteilungen Landesverein Sächsischer Heimatschutz e.V. 3/2014, 23-28.

7 W. Ender, A. Kinne und R. Vogt, Das Gräberfeld auf dem Tanzberg von Prositz/Piskowitz (Lkr. Meißen). Eine archäologisch-bodenkundliche Nachlese. ). In: R. Smolnik (Hrsg.), Ausgrabungen in Sachsen 3. Arbeits- u. Forschber. Sächs. Bodendenkmalpfl. Beih. 24 (Dresden 2012), 83-89. 
account: changes in cultivation method, tillage and crop rotation can be individually agreed upon with farmers. In contrast, measures that interfere with property rights as such as permanent grassland require intensive archaeological assessment and lengthy dialogue. But which measures could be taken to prevent the destructive processes?

\section{Compensatory measures: Eco-accounts}

If nature conservation requirements are met, eco-accounts could be applied to an archaeological site to convert it to an area designated for nature as well as for monument conservation. This lengthy process requires close cooperation between nature conservation and archaeological heritage management agencies. An integrated rural development simplifies the transfer of ownership and the reorganization of land. Since 2011, the Burgberg "Zschaitz", a 6 ha fortification of the early iron and medieval ages covered by grassland, is sustainably protected (Fig. 8). ${ }^{8}$ The eco-accounts are marketed by the Sächsische Landsiedlungs $\mathrm{GmbH}$ to refinance the purchase of land.

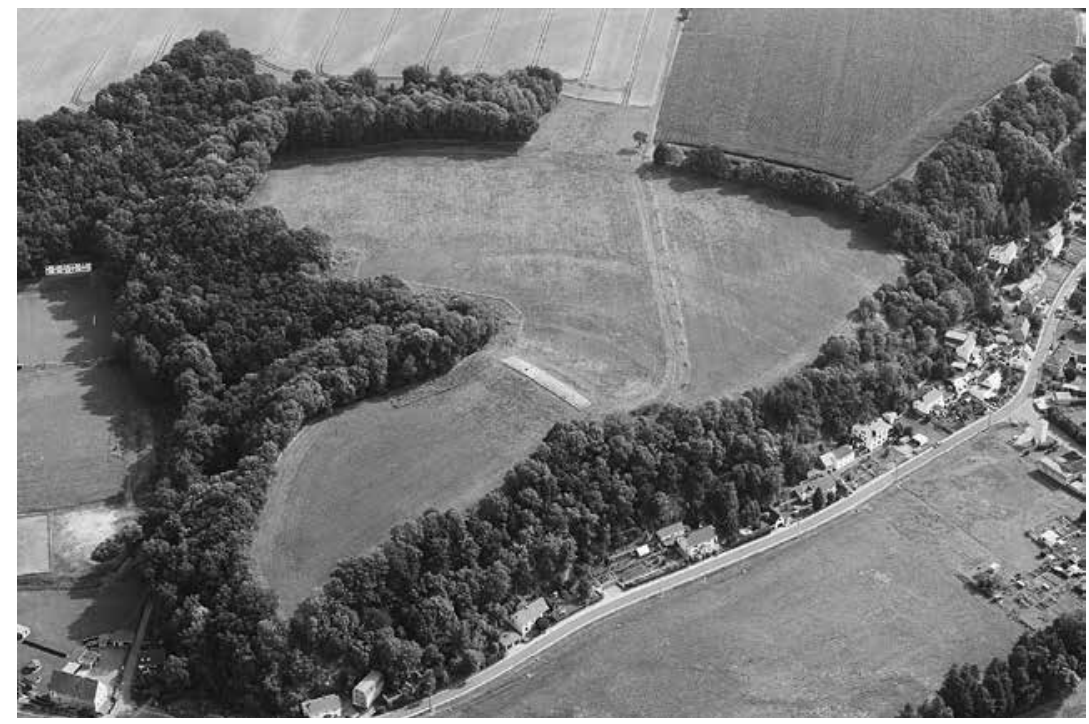

Fig. 8 The prehistoric and medieval fortification "Burgberg Zschaitz" has been converted to a compensation area on the base of eco-accounts and is sustainably protected (Foto. R. Heynowski).

8 V. Bromme et al., Der Burgberg Zschaitz in der Lommatzscher Pflege - Landschaft, Natur und Archäologie. Archaeonaut 9 (Dresden 2010). S. Bens et al., Zukunft für ein bedeutendes archäologisches Kulturdenkmal - der Burgberg Zschaitz. ). In: R. Smolnik (Hrsg.), Ausgrabungen in Sachsen 3. Arbeits- u. Forschber. Sächs. Bodendenkmalpfl. Beih. 24 (Dresden 2012) 100-108. 
Nonetheless, the negotiations are normally complex, difficult and require considerable time while the creeping destruction of the monument is still going on. Until a permanent solution for its future is found, intermediate, but temporary measures can help to stop these processes. At the moment, we can hope to achieve a similar solution for the early medieval fortification of Hof-Stauchitz. The Sächsische Landsiedlungs $\mathrm{GmbH}$ has already initiated the negotiations with landowners, tenants and the nature conservation authorities.

\section{Set-aside areas for ecological purposes}

In an intensively used landscape farmers don't tend to set aside fertile farmland for nature conservation objectives, but only areas of marginal productivity. The edges of the Mulde river valley, small-scale agricultural units, are not attractive for modern farming and cultivated restrictively. Once again, different objectives have to be harmonized. There is no monument without nature conservation.

\section{Highly biodiversity grassland}

That's why archaeological sites located near to FFH-areas have the greatest opportunity to be converted. The protection status is funded by the Agricultu$\mathrm{ral} /$ nature program of the Freistaat Sachsen. Even the "Zöthainer Schanze", a fortified site of medieval age, takes benefit from this proximity (Fig. 9).

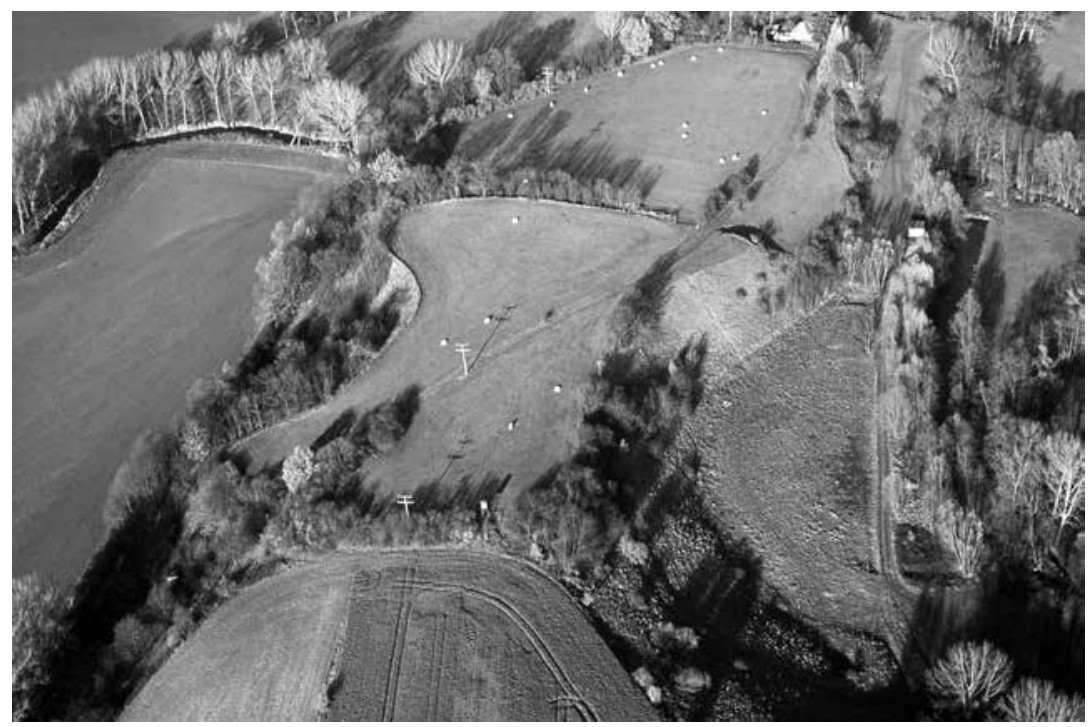

Fig. 9 Medieval fortification of "Zöthain" is effectively protected under grassland (Foto: R. Heynowski). 


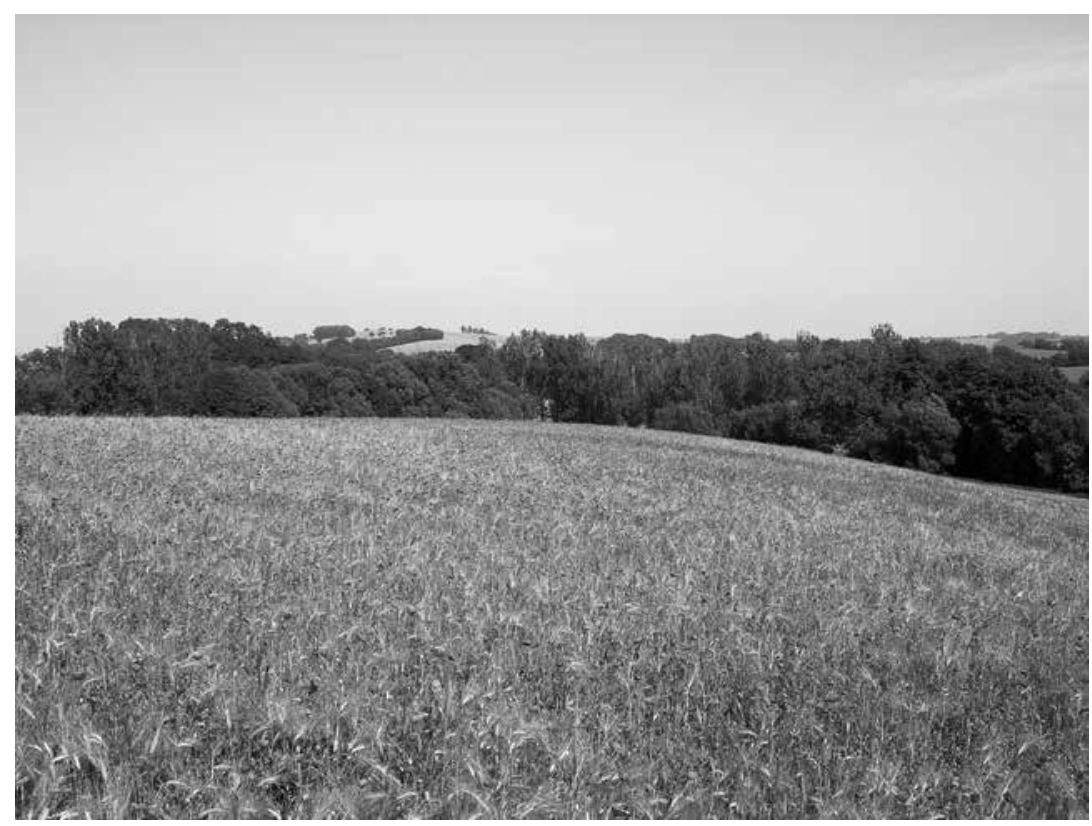

Fig. $10 \mathrm{~A}$ conservation field is preventing the damage of a Bronze Age settlement.

\section{Conservation field for wild herbs and extensive farming.}

Wild herbs have disappeared largely from farmland for decades, eliminated by plant protection products. In the 1980s a farming company and environmentalist encouraged the reintroduction of native species on a small marginal loess hill occupied during the Bronze Age (Fig. 10). The area purchased by the "Landesverein Sächsischer Heimatschutz" some years ago is leased to a farmer that is specialized in seed multiplication and an extensive cultivation of fields. His careful management also protects the prehistoric settlement as well as the wild herbs.

\section{Afforestation and increasing forest areas}

Afforestation is the worst of all possible solutions, but sometimes better than intensive farming. Burial mounds and fortifications enjoyed the best protection under wood for centuries. Forest thinning must be in accordance with the monument and compatible to visible structures. Only marginal farmland is suitable for afforestation. A plateau overlooking the Mulde Valley, occupied since the Neolithic and fortified during medieval times, was intensively farmed until 2004. Now, young trees and an incomplete forest provide a better protection. The afforestation was funded by the Saxon agri-environmental program (increasing forest areas). 


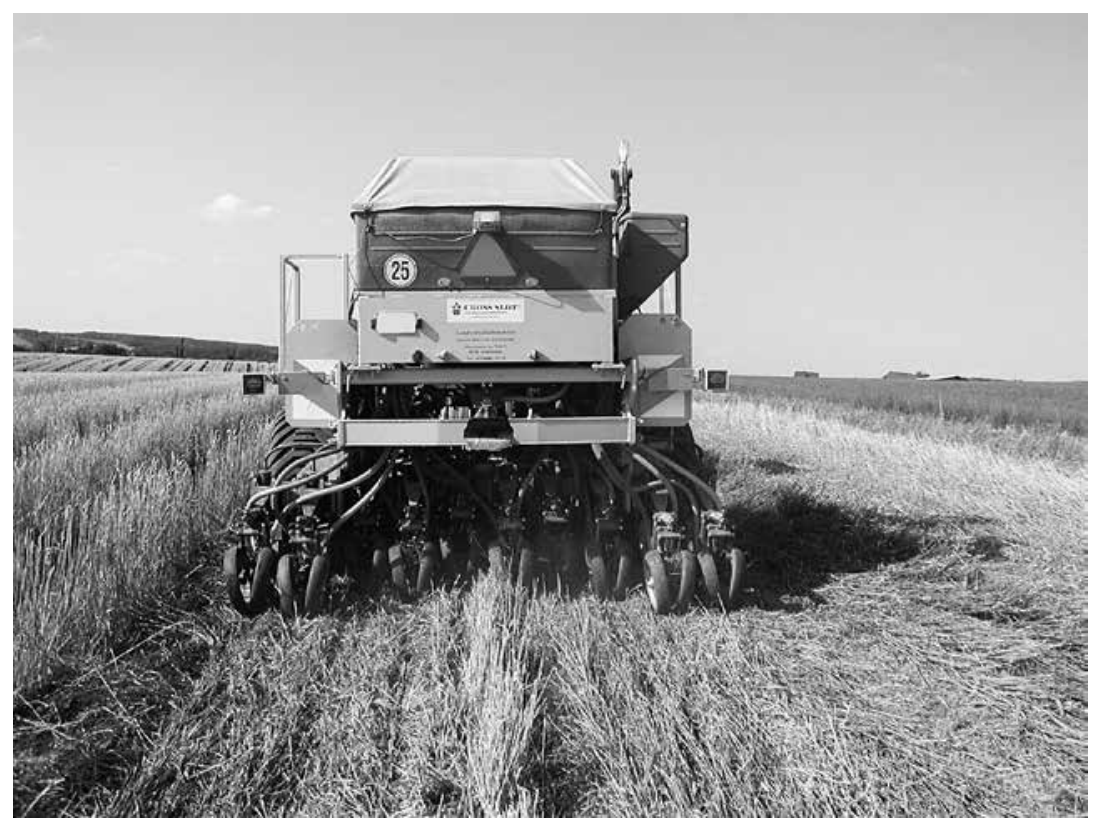

Fig. 11 Direct sowing could be an effective approach to a better protection of archaeological sites in arable landscapes. (Copyright: Sächsisches Landesamt für Umwelt, Landwirtschaft und Geologie)

\section{Direct sowing}

In Saxony, plough less soil tillage or conservation tillage is no longer be subsidized with the exception of the strip and direct sowing (Fig. 11). Although the effects of soil protection are comparable to grassland the technology is rarely applied. Companies shy away from a total farm conversion and are afraid of massive revenue losses. Only one farmer has successfully implemented direct sowing in Saxony, but outside the zones of archaeological relevance. However, about one-quarter of the arable land in the "Lommatzscher Pflege" is cultivated completely ploughless with positive effects on the archaeological remains because mulch sowing is stimulating the percentage of organic matter and limiting the depth of plowing.

\section{Grassland strips}

In combination with minimum tillage grassland stripes shown on the top of slopes, on the borders of small rivers and in water pathways (Fig. 12) contribute to a better prevention of water erosion. 


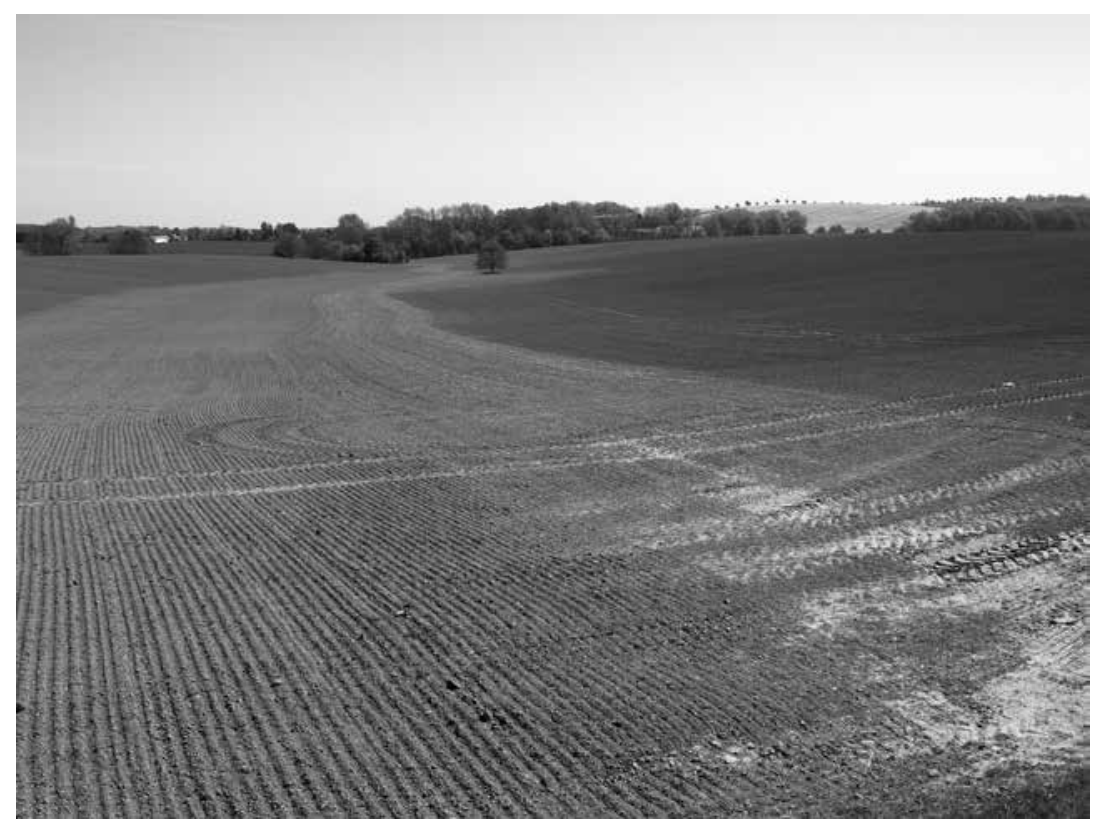

Fig. 12 Grassland strips in water pathways contribute to prevent water erosion.

\section{Precision Farming applications}

It would be fanciful to believe that a fertile loess-hill region and productive agricultural landscape could be transformed into grassland. We prefer production integrated measures that reconcile farming and the conservation of archaeological monuments as well as the protection of ground-nesting birds. Generally, several distinct protection objectives improve the opportunities for fundraising and taking measures.

Precision farming applications are considered the solution which best meets this criterion (Fig. 13). For the first time, a site-adapted, GPS-based cultivation was tested four years ago. An agricultural service provider drew and implemented a map integrating fields and keep-out areas (monuments). When the tractor approached an archaeological site, the driver was warned by an acoustic signal. The cultivation depth should be adjusted not automatically, but by hand and interrupted operating schedules accustomed to the drivers. Also, the manual data updates on board needed more qualification and experience than the drivers generally have. In consequence, the test revealed the impractical procedure.

Obviously, a new project must take account of farmer's needs and involve other protected assets, for instance, skylark plots without crop seeds for ground-nesting birds, field borders or flower strips. All data have to be transferred automatically from the farmer's personal cloud to the tractor's terminal including 


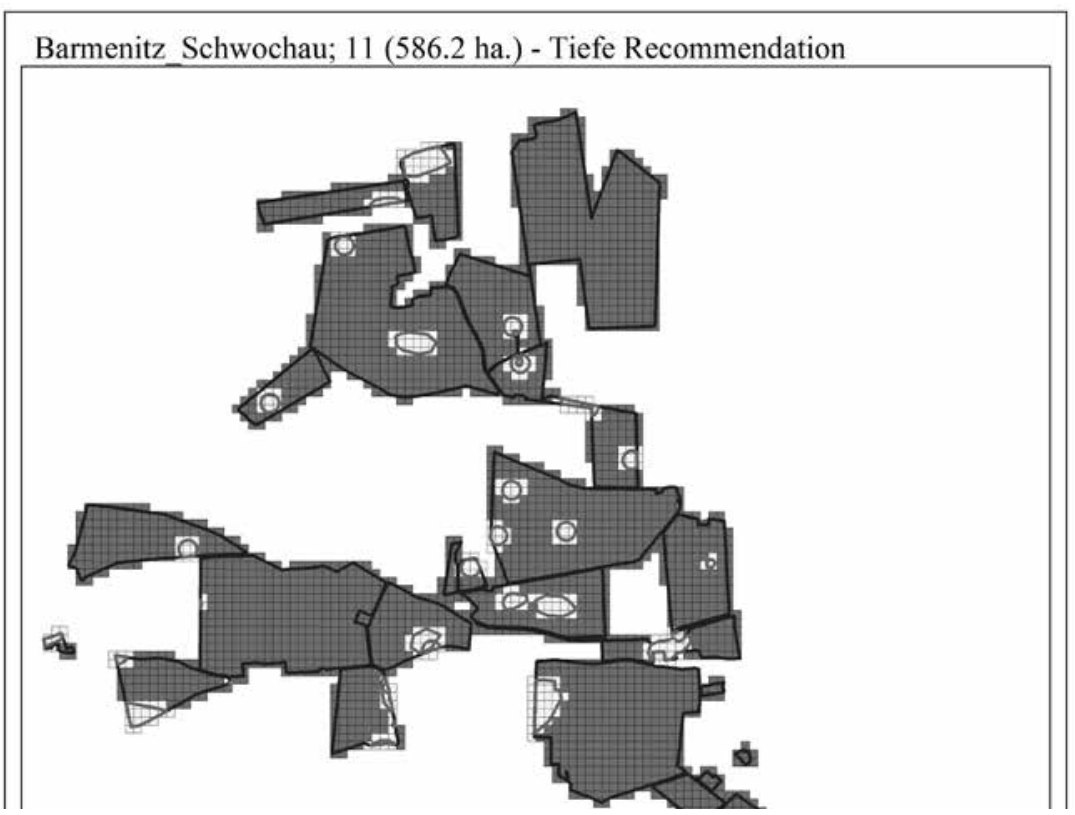

Fig. 13 Precision farming solutions could be a promising approach in order to reduce the depth of ploughing more purposefully.

the grubber's hydraulic control or the plant protection sprayer. Regarding these conditions, the Saxon State Office for Environment, Agriculture and Geology approved a project funded by the European program EIP Agri ("European Innovation Partnership", "agricultural productivity and sustainability"). 9

The data transfer and input has been solved now. Completely protected areas are surrounded by field boundaries. In order to adjust and to reduce the working depth, an application map is drawn constraining the depth. For this purpose ISOXML-orders stored in the "personal cloud" is modified; synchronizing data between the personal cloud and the tractor's onboard computer is performed by a Raspberry Pi-Station and a WLAN-flash USB stick. In autumn 2017 the system is going to be tested in the field.

\section{Conclusions}

In intensively used agricultural landscapes archaeological remains are still damaged by erosion, cultivation and pollutant inputs to the soil. The creeping processes can't be routinely managed and mitigated. The absence of any structured archaeological response remains a significant challenge to the management of archaeological monuments in rural landscapes. But the implementation of concrete measures needs more than sensitive archaeological institutions. Without

9 https://news.exagt.de/news.exagt.de/. 
the cooperation with farmers, agricultural administrations, nature conservation agencies and organizations as well as the mobilization of agro-environmental funds archaeologists will never achieve to an efficient heritage management on intensively cultivated areas. In order to protect the rural archaeological heritage in Saxony, various strategies have been developed since 2000. Especially the conversion of ploughed sites into grassland alongside with the application of precision farming systems are different approaches to a better conservation of archaeological remains at risk.

In most cases the measures are temporary, depending on the willingness of different stakeholders and specific support programs. Only the purchase of land ensures a sustainable protection of monuments.

\section{Rezumat}

Nicăieri nu există o distrugere mai sistematică și mai lentă a monumentelor arheologice ca în peisajele agricole intens utilizate. Locațiile sunt încă degradate prin eroziunea, cultivarea și introducerea de poluanți în sol. Dar punerea în aplicare a măsurilor concrete necesită mai mult decât instituții arheologice sensibile. Fără cooperarea cu fermierii, administrațiile agricole, agențiile şi organizațiile de conservare a naturii, precum și mobilizarea fondurilor agro-ecologice, arheologii nu vor reuși niciodată să realizeze o gestionare eficientă a patrimoniului pe suprafețe intens cultivate. Pentru a proteja patrimoniul arheologic rural din Saxonia, au fost elaborate diferite strategii începând cu anul 2000. Lucrarea prezintă modele de bune practici de gestionare a monumentelor în peisajele agricole intens utilizate. Mai ales conversia siturilor cultivate în păşuni, alături de aplicarea sistemelor agricole de precizie, sunt abordări eficiente pentru o mai bună conservare a rămăşițelor arheologice în pericol.

Cuvinte-cheies: Agricultura, eroziunea, managementul peisajelor arheologice, regiunea de deal Loess Saxonia de Mijloc, siturile arheologice de risc, aratul 